\title{
Estimation of Internal Rate of Return (IRR) to Investments in Education in Latvia
}

\author{
Linda Romele
}

\begin{abstract}
The objective of the paper is to estimate Internal rate of return (IRR) to education in Latvia based on methodology used by OECD. IRR shows the efficiency of investments in higher education as private return at level of individual. IRR method includes estimation of several factors related to employment probability, pensions and wage premiums, labour taxes.
\end{abstract}

The data of research are based on Labour Force Survey data issued by Central Statistical Bureau of Latvia for year 2010. Objectives of the paper are directly pointed to seeking for methods of recovery of the national economy and further development. The issue of the paper is very urgent as it applies to welfare of the society and growth of human capital.

Index Terms-Employment, IRR, wages

\section{INTRODUCTION}

During economic crisis social policy was subjected to pressure and in many countries budget for social policy and education was cut. However education and training have proven their efficiency and can become important tool in overcoming crisis and promoting development. The Council of the European Union states that: "Efficient investment in human capital through education and training systems is an essential component of Europe's strategy to deliver the high levels of sustainable, knowledge-based growth and jobs that lie at the heart of the Lisbon strategy, at the same time as promoting personal fulfillment, social cohesion and active citizenship" [1]. Therefore it is important to encourage investments in education proving the efficiency of these investments. Rate of return to investments in education has estimated by many economists and two main approaches are used (one is known as investment approach - Net present value and Internal rate of return, the other is based on econometric approach known as Mincer earning function). The author will look more detailed on Internal rate of return approach used also by The Organisation for Economic Co-operation and Development (OECD).

There is opinion that rate of return below $10 \%$ in higher education is evidence of inefficient investment in higher education [2]. However the author would like to argue this opinion pointing out that available data about OECD countries (at different reference period but not older than 2005) show that average private rate of return for men is $12,4 \%$ and for women $11,4 \%$ but social rate of return for men is $10,8 \%$ and for women is $8,8 \%$ [3]. Besides in such countries like

Manuscript received December 10, 2012; revised January 13, 2013. This work has been supported by the European Social Fund within the project "Support for Doctoral Studies at University of Latvia".

Linda Romele is with the University of Latvia, Riga, Latvia and research company Ltd. EPC, Riga, Latvia (e-mail: linda@epc.lv)
Denmark, France, Germany, Italy, Netherland, Norway, Sweden, United Kingdom private rate of return for men and women are below $10 \%$ and it is not directly related to efficiency of investments in education in mentioned countries. The returns are typically higher for men probably because of larger overall income inequality. Typically public or social rate of return is lower as private rate of return puts forward the advantage of education at individual level. The returns are comparatively lower in Scandinavian countries mainly because of compressed wage structure and higher education system which is almost free of charge. Taxation and social policies in each of the countries are also very important to evaluate the public rate of return. In comparison with previous years rates of return at private and public level have tendency to increase. Rates of return estimated by OECD indicate larger rate of return from higher education than secondary education levels (ISCED 3-4).

The author would like to point out that higher rate of return is estimated in developing countries - for example the private rate of return for men significantly exceed $10 \%$ in such countries like Czech Republic (17,6\%), Hungary (20\%), Poland (21,4\%), Portugal (18,5\%), Slovenia (19,1\%), Turkey $(19,3 \%)$ [4]. In most cases the rate of return is higher for men. Author estimated rate of return using another approach econometric approach developed by Jacob Mincer (1974) using data of Labour Force Survey 2010 and rate of return for women is higher as rate of return for men [4]. Author assumes that it can be explained by lower base work salary for women which make return higher from mathematical perspective. It means that for the same amount of increase men will have lower rate of return. Usually gross earnings are taken into account especially for countries where progressive income tax system is developed. In Latvia equal income tax is applied to all employees and author used net wage. Besides in July 2012 24,8\% from all employees received minimum wage or less which might lead to the thought of high undeclared incomes [5]. In addition people are more aware about their net incomes but not gross work salaries and paid taxes.

Rates of return will be different in countries with high work salary inequality and shortage of highly educated people in some countries as well as it could lead to higher demands for individuals.

OECD estimates the return to education by net present value approach (NPV) which is close to internal rate of return method - both are based on investment approach using discount rate. NPV represents measure of the economic benefit obtained during individual working life related to the costs of higher level of education. Discount rate approach makes it possible to compare costs or payments over the time [6]. However latest researches used combination of two 
approaches estimating IRR based also on Mincerian equation results.

TABLE I: FACTORS OF NET EMPLOYMENT PREMIUM, 2010

\begin{tabular}{|c|c|c|}
\hline Factors & Meaning & Value \\
\hline$\Delta$ & $\begin{array}{l}\text { differential between the } \\
\text { "take-home-pay" rate }(1-\tau) \text { and the } \\
\text { net benefit replacement rate }\end{array}$ & $1-0,2494=0,751$ \\
\hline$\tau$ & $\begin{array}{l}\text { average tax factor for the reference } \\
\text { group, defined as a weighted average } \\
\text { of the average tax rate on labour } \\
\text { earnings and the average tax rate on } \\
\text { unemployment benefits }(3,81 \%) \text {, } \\
\text { with weights given by the } \\
\text { employment and unemployment } \\
\text { probabilities }\end{array}$ & $\begin{array}{l}0,783 * 30,78+ \\
0,221 * 3,81= \\
24,94\end{array}$ \\
\hline$\tau_{\mathrm{o}}$ & Average tax rate on labour earnings & $30,78 \%^{\mathrm{a}}$ \\
\hline \multirow[t]{3}{*}{ p' } & $\begin{array}{l}\text { employability premium, i.e. marginal } \\
\text { increase in the employment } \\
\text { probability from completing the next } \\
\text { higher attainment level per year of } \\
\text { tertiary education }\end{array}$ & $\begin{array}{l}81,1 / 66,1= \\
22,7 \%\end{array}$ \\
\hline & $\begin{array}{l}\text { Average employment rate by } \\
\text { secondary education level (ISCED } \\
3-4 \text { ), age 25-64 }\end{array}$ & $66,1 \%$ \\
\hline & $\begin{array}{l}\text { Average employment rate by higher } \\
\text { education level (ISCED 5-6), age } \\
25-64\end{array}$ & $81,1 \%$ \\
\hline \multirow[t]{3}{*}{$\mathrm{S}^{\prime}\left(\mathrm{X}_{0}\right)$} & $\begin{array}{l}\text { Survival rate (the ratio of the number } \\
\text { of students who are awarded an initial } \\
\text { degree to the number of new entrants } \\
\text { to the level n years before, } n \text { being the } \\
\text { number of years of full-time study } \\
\text { required to complete the degree [ } 4 \text {, } \\
\text { Glossary]) } \\
\text { Author assumed that average number } \\
\text { of full-time study } n=4 \text { years. }\end{array}$ & $58,95 \%$ \\
\hline & $\begin{array}{l}\text { Number of students who are awarded } \\
\text { in } 2010\end{array}$ & 26541 \\
\hline & Number of new entrants in 2006/2007 & 45025 \\
\hline
\end{tabular}

One of the main investment costs is foregone earnings which depends from wage levels in particular countries and length of study. Other indicators of private return to investments in education are probability to find a job (unemployment rate), taxes and private costs of education. Therefore education expenses should be covered by higher incomes in future to recover direct and indirect expenses of education and foregone earnings as well. Besides length of education, work salary amount, unemployment rate and access to labour market are taken into account. Access to education depends as well in each country by supporting system (supported mainly by state or partly by individuals and state). OECD calculates foregone earnings at level of the legal minimum wage or earnings which include part-time work [7].

Public benefits from investments in higher education are lower social expenses (in case of unemployment) and others social benefits supported by state budget, higher incomes from taxes (in case of progressive income tax), higher incomes from consumption taxes, higher social insurance contributions in current social budget (if social insurance taxes linked to current expenditures from social budget for pensions not for savings). However indirect costs such as foregone taxes should be taken into account. Public costs include foregone tax incomes (income and social insurance taxes) and public expenditures of education (direct and indirect such as state grants to students).

$$
N P V=-\sum_{t=0}^{d-1} C_{t} /(1+i)^{t}+\sum_{t=d}^{64-a-d} B_{t} /(1+i)^{t}
$$

$C_{t}-$ costs at period t

$B_{t}-$ benefits at period $\mathrm{t}$

$d$ - duration of studies

$a$ - age at the beginning of activity in the labour market

Costs are composed of following costs:

Foregone earnings + direct private expenditures - grants allocated + increased future taxes + lost transfers

Benefits are composed of following benefits:

Increases in earnings + higher probability of being employed (unemployment effect, 1 minus unemployment rate applied to average annual salary).

\section{ESTIMATION OF INTERNAL RATE OF RETURN}

Author estimates IRR - internal rate of return which is composed of several influencing factors. We will use formula provided by Angel de la Fuente and Juan F. Jimeno and used as well by Romina Boarini and Hubert Strauss [8], [9].

$P^{\prime}{ }_{\text {net }}$ is the net employability premium estimated as $=\Delta \mathrm{p}$ ' $\mathrm{S}^{\prime}\left(\mathrm{X}_{0}\right)=0,751 \times 0,227 \times 0,5895=0,1005$

All tax rates incorporate personal income taxes and employee social insurance taxes (except employers' taxes).

$\theta_{\text {net }}($ net wage premium $)=\mathrm{p}\left(1-T^{\prime}\right)\left[\theta \mathrm{S}^{\prime}\left(X_{0}\right)-v\right]=0,661$ $0,7175[0,1038 \times 0,5895-0,0088]=0,0248$

TABLE II: FACTORS OF NET WAGE PREMIUM, 2010

\begin{tabular}{|l|l|l|}
\hline Factors & Meaning & Value \\
\hline$p$ & $\begin{array}{l}\text { employment probability for people with } \\
\text { upper-secondary education }\end{array}$ & $66,1 \%$ \\
\hline \multirow{5}{*}{,} & $\begin{array}{l}\text { marginal tax factor for a person of the reference } \\
\text { group, defined as a 'weighted' average of the } \\
\text { marginal tax rate on labour earnings and the } \\
\text { marginal tax rate on unemployment benefits } \\
(3,81 \%), \text { with weights given by the } \\
\text { employment and unemployment probabilities }\end{array}$ & $\begin{array}{l}0,783 \times 35,0 \\
+ \\
0,221 \times 3,81= \\
28,25\end{array}$ \\
\hline \multirow{2}{*}{$\theta$} & $\begin{array}{l}\text { marginal tax rate on labour earnings } \\
\text { (see explanation: Mincerian wage equation) }\end{array}$ & $35 \%$ \\
\hline $\mathrm{S}^{\prime}\left(\mathrm{X}_{0}\right)$ & \begin{tabular}{l} 
Survival rate \\
\hline \multirow{5}{*}{$\begin{array}{l}\text { labour market experience premium } \\
\text { Author used the data (experience premium) } \\
\text { obtained from Mincerian wage equation } \\
\text { (0,0091 in case of man and 0,0085 in case of } \\
\text { women, weighted average is equal to 0,0088) }\end{array}$}
\end{tabular} & $\mathbf{5}$ \\
\hline
\end{tabular}

Mincerian wage equation:

According to this method such factors as average years of schooling, the age of employee, average net income of employee and work experience are taken into account [10]. The results indicate the average rate of return from one additional year of schooling by gender and average for all working population with gender employment weights. The data of research are based on Labour Force Survey data issued by Central Statistical Bureau of Latvia for year 2010. Author made several restrictions on general random. As a result research covers data of about 6140 employees which is statistically significant.

$$
\ln Y_{s, x}=\ln Y_{0}+r s+\beta_{1} x+\beta_{2} x^{2},
$$

where $x$ : years of experience

$Y_{s, x}$ : annual earnings of an individual with $\mathrm{s}$ year of schooling and work experience $x$ 
$Y_{0}$ : earning capacity after completion of schooling

$S$ : years of schooling

$r$ : rate of return

In case of men rate of return $r=0,0925$ which is equal to $9,25 \%$. In case of women education has higher rate of return and exceeds 11, 44\% from each additional year of schooling however it can be explained by comparatively lower base work salary.

To estimate the average Mincerian rate of return the author uses weights of women and men employment. Taking into account employment of women and men in age group $20-64$ we get average Mincerian rate of return which is equal to 0 , $484238 \times 9,25+0,515762 \times 11,44=10,38 \%$ [11].

$\operatorname{PENS}(\mathrm{R})$ pension premium $=\gamma(R)\left(1-T_{p}{ }^{\prime}\right) k\left[\theta \mathrm{S}^{\prime}\left(X_{0}\right)-v\right]$ $=0,063 \times 0,74 \times 0,56[0,1038 \times 0,5895-0,0088]=0,026 \times$ $0,0524=0,0014$

$$
\gamma(R)=\frac{R}{R+g+v-\dot{\omega}} \frac{1-e^{-(R+g+v-\dot{\omega})(Z-U)}}{e^{R H}-1}
$$

TABLE III: FACTORS OF PENSION PREMIUM, 2010

\begin{tabular}{|l|l|l|}
\hline Factors & Meaning & Value \\
\hline \multirow{5}{*}{$\gamma(\boldsymbol{R})$} & Discount factor on pension benefits & $R=10,38-3,87-$ \\
& $R=r-g-v$ & $0,0088=6,50$ \\
& $g=$ labour productivity growth over the & $\gamma(R)=0,06294$ \\
& past decade & $(2001-87 \%$ per year \\
& (author used Mincerian equation & $v=0,0088$ \\
& results) & $\omega=12,04 \%$ per \\
& $\omega=$ real growth rate of pensions & year $(2001-$ \\
& $Z=$ life expectancy at birth & $Z=73)^{\mathrm{a}}$ \\
& $U=$ average retirement age & $U=60,93$ year \\
& Marginal income tax rate for pensioners & $26 \%$ \\
\hline$T_{p}{ }^{\mathrm{c}}$ & Pension benefit replacement rate & \\
\hline \multirow{5}{*}{$k$} & The author estimated replacement ratio & $175,88 / 316=0,56$ \\
& as average net incomes while working & \\
& to net average pension, 2010 & \\
\hline
\end{tabular}

$a-$ SDG03. Average size of pensions paid (lats). www.csb.gov.lv

$b$ - IMG07. Average life expectancy at birth (years).

www.csb.gov.lv

$c$ - Data of the State Social Insurance Agency.

The author estimated average retirement age using D. Latulippe methodology based on assumptions about minimum retirement age at 45 , distribution of population, retirement and activity rates referring in five years groups [12]. In this case the average retirement age is 59, 61 years. Further author will use the official retirement age estimated by State Social Insurance Agency which is equal to 60, 93.

$R$ combines $r$ the private return to schooling (at which the future stream of income is discounted) with $g$ and $v$.

OPPC (opportunity cost of schooling) $=p(1-\tau)=0,661$ $\times 0,751=0,496$

DIRC $($ direct cost of schooling $)=\mu e^{\mathrm{vH} 0 / 2}=0,1299 \times e^{0,19}$ $=0,1569$, where

$\mu-$ is direct private cost of tertiary education, expressed as a fraction of the wage of an upper-secondary degree holder.

In Latvia private expenditure on higher education was 54, 9 million LVL equal to 78,12 million euro (Latvian Bank official rate $0,702804 \mathrm{LVL}=1$ euro)

The author estimated average number of students in 2010 taking into account drop out, number of graduates and new students.

$$
V=\mathrm{S}_{-1}(1-1 / 3 k)(1-1 / 2 k)+1 / 3 \mathrm{U}-1 / 2 B=95370, \text { where }
$$

$k$ - drop-out rate in $2010=0,157$

$S-1$ - the number of total students on previous year 1 st October $=112555$

$U$ - the number of students enrolled in $2010=30944$

$B$-the number of students who obtained degree or qualification in $2010=26541$

The private expenditure does not include indirect costs of higher education (for example living costs or accommodation rent) but mainly covers direct costs like tuition fees, books. The average private spending on higher education was 575 LVL or 819 euro which is $12,99 \%$ from average wage of an upper-secondary degree holder. The estimated rate shows the fraction of wage which should be allocated or invested from private resources obtaining higher education.

The average wage of an upper-secondary degree holder was 6305 euro in 2010 (ISCED 3-4 levels, NACE sectors B-S (Industry, construction and services (except activities of households as employers and extra-territorial organisations and bodies).

$H=$ length of the working life. The author used Mincer approach $\mathrm{U}-\operatorname{Max}\left(6+\mathrm{S}_{0}\right)$ where 6 is schooling starting age and $S_{0}$ average length of education.

The author used the methodology of Robert J.Barro and Jong-Wha Lee to estimate average length of education [13]. The indicator is estimated taking into account the share of people who obtained particular level of education, share of population referring in five years groups and average number of schooling in each level of education.

The average years of education in 2010 (age $25-64$ ) was 12,45 years. From this we get $\mathrm{H}=60,93-6-12,45=42,48$ years.

$H_{0}$ is retirement age of an upper-secondary degree holder and it is equal $H_{0}=60,93-6-12=42,93$ years.

$$
\mathrm{IRR}=\frac{\theta \text { net }+P^{\prime} \text { net }+ \text { PENS }(R)}{O P P C+D I R C}=19,40 \%
$$

The results indicate relatively high private internal rate of return which is typically for new EU member states and developing countries.

Author stressed that all used indicators indicate average "temperature" in the country and include differences between employees with high and low incomes where Gini coefficient in Latvia is very high (in Latvia it was $36,1 \%$ in 2010 in comparison with $30,5 \%$ in EU27) [13]. However it shows the tendencies and it is rather good indication where return from private investments in education is high and valuable. It is estimated that increase in net wage premium and net employability premium have direct and positive effect on private internal rate of return. Increase by 3 percentage points on wage premium it is expected the increase of internal private rate of return by 1,25 percentage points which shows that wage increase from one additional year of schooling increase faster than expected increase from labour market and social benefits. For example, increasing employment probability for employees who have higher education by 3 percentage points the private internal rate of return will also increase by 3 percentage points. In addition the increase in private costs for higher education as tuition costs the expected private internal rate of return will decrease which leads to negative feedback from private investments in education. 


\section{REFERENCES}

[1] Council conclusions of 12 May 2009 on a strategic framework for European cooperation in education and training ('ET 2020'). [Online]. Available:

http://europa.eu/legislation_summaries/education_training_youth/gen eral_framework/ef0016_en.htm

[2] Şnitnikovs. (2002). The economic return of higher education in Latvia. Ekonomiskā atdeve no augstākās izglītības Latvijā. Riga: Sorosa fonds-Latvija. [Online]. Available: www.politika.lv/index.php?f=472

[3] Education at a Glance, OECD, Paris, 2012 edition, pp.174-181.

[4] J. Mincer, Schooling, experience and earnings, Cambrige, MA: National Bureau of Economic Research, 1974.

[5] DS14. Breakdown of number of employees by income by sector, The Central Statistical Bureau of Latvia.

[6] Education at a Glance, OECD, Paris, 2012 edition, pp.167

[7] A. D. L. Fuente and J. F. Jimeno, "The private and fiscal returns to schooling and the effect of public policies on private incentives to invest in education: a general framework and some results for the EU," CESifo Working Paper, no. 1392, 2005.

[8] R. Boarini and H. Strauss, "The Private Internal Rates of Return to Tertiary Education: New Estimates for 21 OECD Countries," OECD Economics Department Working Papers, no. 591, OECD Publishing, 2007.

[9] J. Mincer, Schooling, experience and earnings, Cambrige, MA: National Bureau of Economic Research, 1974.

[10] NBG01.Population by labour status and sex 2010, The Central Statistical Bureau of Latvia.

[11] D. Latulippe. Effective retirement age and duration of retirement in the industrial countries between 1950 and 1990. [Online]. Available: http://www.ilo.org/gimi/gess/RessShowRessource.do?

[12] R. J. Barro and J. W. Lee, "A new data set of educational attainment in the world, 1950 - 2010," The National Bureau of Economic research, no. 15902, April 2010.

[13] NIG12.Gini coefficient (\%), The Central Statistical Bureau of Latvia.

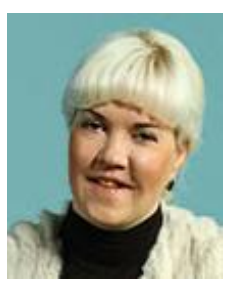

Linda Romele was born in capital of Latvia , Riga on 12 April 1977. She has two master degrees on Business Administration (2001) and Communication Science (2004), both at the University of Latvia. The major field of study is labour and education economics.

She participated in fellowship in London, 2010 at Labour Research Department. She has wide experience in social issues - she has been social projects manager for more than 7 years at Free Trade Union Confederation of Latvia. Currently she develops International social and education projects at Baltic Computer academy in Riga. The main publications concern different social and economic issues - mainly working time, flexicurity, education impact on labour productivity and training at work place, work salary in public sector, efficiency of investments in education based on different approach, working conditions in Latvia (published by Eurofound).

Linda Romele is PhD Candidate at University of Latvia. Currently she is the researcher in the Project „Information services: quality of work and employment, industrial relations and restructuring and management of change - Latvia" (2010 - 2013) by European Foundation for the Improvement of Living and Working Conditions (Eurofound, Dublin) as well. She has been member of Governing Board of Eurofound in Dublin, member of European Social Fund Committee of European Commission in Brussels and member of European Trade Union Confederation Lifelong Learning Committee in Brussels more many years. She has participated in several projects under Ministry of Education and Science as expert on vocational education. 